\title{
STRATEGI PENGEMBANGAN PANGKALAN PENDARATAN IKAN CISOLOK, KABUPATEN SUKABUMI: PENDEKATAN ANALISIS SWOT
}

\section{THE DEVELOPMENT STRATEGY OF CISOLOKFISH LANDING BASE, SUKABUMI REGENCY: SWOT ANALYSIS APPROACH}

\author{
Ayang Armelita Rosalia ${ }^{1}$, A.B. Pane ${ }^{2}$, Iin Solihin ${ }^{2}$, Roma Yuli F. Hutapea ${ }^{3}$, Aprilia Syah Putri ${ }^{4}$, Denta Tirtana ${ }^{5}$ \\ ${ }^{1}$ Program Studi Sistem Informasi Kelautan, Universitas Pendidikan Indonesia \\ ${ }^{2}$ Departemen Pemanfaatan Sumberdaya Perikanan, Fakultas Perikanan dan Ilmu Kelautan, Institut Pertanian Bogor \\ ${ }^{3}$ Program Studi Perikanan Tangkap, Politeknik Kelautan dan Perikanan Dumai, Kementerian Kelautan dan Perikanan \\ ${ }^{4}$ Program Studi Perikanan Tangkap, Jurusan Peternakan, Politeknik Negeri Lampung \\ ${ }^{5}$ Alumni Program Studi Teknologi Perikanan Laut, Fakultas Perikanan dan Ilmu Kelautan, Institut Pertanian Bogor \\ Korespondensi: ayang.armelita@upi.edu
}

\begin{abstract}
Cisolok Fish Landing Base (CFLB) cannot be used optimally, because the main facilities for the fish landing dock and port pool are no longer be implemented and cannot accommodate all Cisolok fishing vessels. The condition of the fish landing dock and port pond which are not functioning optimally, has resulted in the need for the development of main facilities at CFLB. The objective of this study is to obtain an important strategy for the development of fish landing facilities and activities related to the development of main port facilities for CFLB managers, namely; fish landing docks and port pond. The method used is a case study. The data analysis by using SWOT (Strength-WeaknessOpportunity-Threats) analysis. The important strategies that can be applied in the development of CFLB facilities includes: (1) Carry out the gradual construction of main facilities (fish landing dock and port pond), (2) performing a breakwater by extending the length of the breakwater along the coast to the left and right of the port, (3) dredging sedimentation so that motorboats can enter CFLB, and (4) increasing the size and number of the fishing vessel.
\end{abstract}

Keywords: fishing port, jetty, silting

\begin{abstract}
ABSTRAK
Pangkalan Pendaratan Ikan (PPI) Cisolok tidak dapat digunakan secara maksimal, karena fasilitas pokok dermaga pendaratan ikan dan kolam pelabuhan yang ada sudah tidak layak dan tidak dapat menampung seluruh kapal ikan nelayan Cisolok. Kondisi dermaga pendaratan dan kolam pelabuhan yang tidak berfungsi secara optimal, menyebabkan diperlukannya pengembangan fasilitas pokok di PPI Cisolok. Tujuan dari penelitian ini untuk memperoleh strategi penting dalam pengembangan fasilitas dan aktivitas pendaratan ikan, yang berkaitan dengan pengembangan fasilitas pokok pelabuhan bagi pengelola PPI Cisolok yaitu; dermaga pendaratan ikan dan kolam pelabuhan. Metode yang digunakan adalah studi kasus. Analisis data yang dilakukan menggunakan Analisis SWOT. Strategi penting dalam pengembangan fasilitas-aktivitas di PPI Cisolok meliputi: (1) Melakukan pembangunan secara bertahap fasilitas pokok (dermaga pendaratan ikan dan kolam pelabuhan), (2) Melakukan perbaikan breakwater dengan menambah panjang breakwater di sepanjang pantai sebelah kiri dan kanan pelabuhan, (3) Melakukan pengerukan sedimentasi sehingga Kapal Motor (KM) dapat masuk ke PPI Cisolok, dan (4) Peningkatan ukuran dan jumlah armada penangkapan ikan.
\end{abstract}

Kata kunci: dermaga, pelabuhan perikanan, pendangkalan 


\section{PENDAHULUAN}

Pelabuhan perikanan merupakan pusat pengembangan ekonomi suatu wilayah perikanan. Keberadaan pelabuhan perikanan sangat penting dalam pengembangan industri perikanan. Pelabuhan perikanan mempunyai fungsi antara lain untuk meningkatkan dari aspek pra produksi, produksi, pengolahan, dan pendistribusian (Lubis 2012).

Penelitian tentang pengembangan pelabuhan telah dilakukan di beberapa pelabuhan perikanan yaitu Pangkalan Pendaratan Ikan (PPI) Lampulo Banda Aceh (Syahputra 2015), Pelabuhan Perikanan Nusantara (PPN) Pengambengan Jembrana (Suherman 2011), Pelabuhan Perikanan Samudera Nizam Zachman Jakarta (PPSNZJ) (Sinaga et al. 2013) dan PPN Karangantu Kota Serang Provinsi Banten (Puspitasari et al. 2013). Wahyudi (2014) menyatakan bahwa, PPI Cisolok dipersiapkan untuk mengganti fungsi PPN Palabuhanratu sebagai tempat berlabuh bagi kapal-kapal yang berukuran kecil yaitu 30 GT ke bawah. Hal tersebut dikarenakan PPN Palabuhanratu saat ini sedang mempersiapkan untuk meningkatkan statusnya menjadi Pelabuhan Perikanan Samudera (PPS).

Keterbatasan fasilitas yang tersedia di PPI Cisolok dapat menghambat aktivitas pendaratan ikan di PPI Cisolok, karena aktivitas dan fasilitas di suatu pelabuhan perikanan memiliki hubungan yang erat. Apabila jenis dan jumlah fasilitas yang tersedia di pelabuhan perikanan tidak memenuhi kebutuhan, maka kondisi tersebut akan menghambat proses aktivitas, terhambatnya aktivitas yang berlangsung dapat mengakibatkan penurunan kualitas hasil tangkapan. Hal ini sesuai dengan pernyataan Lubis \& Mardiana (2011) bahwa keberadaan fasilitas sangat berperan dalam menunjang aktivitas di suatu pelabuhan perikanan.

Kondisi fasilitas pokok dermaga pendaratan ikan dan kolam di PPI Cisolok tidak dapat menampung seluruh jumlah kapal ikan nelayan Cisolok, karena kondisi fasilitas yang ada sudah rusak dan tertimbun bahan sedimen berupa pasir, sehingga nelayan Cisolok harus mendaratkan ikan ke pinggir pantai dan sekaligus sebagai tempat pengisian bahan kebutuhan melaut. Kondisi fasilitas pokok dermaga pendaratan ikan dan kolam tidak berfungsi secara optimal di PPI Cisolok, menyebabkan diperlukannya pengembangan fasilitas pokok di pelabuhan ini. Fasilitas dermaga dan kolam PPI Cisolok perlu dikembangkan sesuai dengan kebutuhan aktivitas, untuk mengantisipasi kebutuhan aktivitas pada saat ini dan masa yang mendatang. Hal ini sesuai pula dengan pendapat Indrayani et al. (2017), perlu melakukan pengembangan fasilitas dermaga dan kolam pelabuhan di PPIPPI yang berada di Kabupaten Sukabumi, sehingga para pengguna pelabuhan dapat melakukan aktivitasnya dengan baik.

Strategi pengembangan perlu dilakukan supaya fungsi fasilitas pokok tersebut berlangsung dengan tepat, terarah, dan berhasil dengan baik. Sebagaimana pernyataan Putri et al. (2017), bahwa pelabuhan perikanan perlu pengelolaan yang baik untuk mengoptimalkan fungsi pelabuhan perikanan tersebut. Strategi pengembangan tersebut dirancang dengan mempertimbangkan faktor-faktor internal dan eksternal di PPI Cisolok.

Strategi pengembangan yang tepat diharapkan akan mampu memberikan kontribusi yang optimal terhadap berbagai aktivitas yang terdapat di PPI Cisolok. Strategi pengembangan fasilitas dan aktivitas memiliki tujuan jangka panjang dari pelabuhan perikanan untuk mengembangkan fasilitas yang tersedia, kemudian akan meningkatkan aktivitas di pelabuhan. Banyaknya aktivitas akan menentukan berapa besar fasilitas yang dibutuhkan agar aktivitas di pelabuhan berjalan baik dan lancar. Pengembangan dilakukan dengan strategi yang berkaitan dengan potensi pelabuhan diantaranya kekuatan dan kelemahan, untuk menentukan alternatif strategi yang akan digunakan dalam pengembangan fasilitasaktivitas pelabuhan.

\section{METODE PENELITIAN}

Penelitian lapangan dilaksanakan pada bulan Agustus sampai dengan Oktober 2017, bertempat di Pangkalan Pendaratan Ikan Cisolok, Kecamatan Cisolok, Kabupaten Sukabumi. Jenis data yang dikumpulkan dalam penelitian ini adalah data primer dan data sekunder. Data primer yang diperoleh dari hasil pengamatan secara langsung di lapangan terkait keadaan fasilitas dermaga, kolam pelabuhan, dan keadaan aktivitas pendaratan mulai dari palka hingga ke Tempat Pelelangan Ikan (TPI) dan hasil wawancara langsung di lapangan dengan 
menggunakan daftar pertanyaan kuesioner. Penentuan responden menggunakan teknik pemilihan sampel secara purposive sampling. Responden yang diambil pada penelitian ini yaitu 6 orang pengelola PPI Cisolok dan Dinas Kelautan dan Perikanan (DKP), 5 orang nelayan, dan 4 orang pedagang. Data sekunder yang diperoleh dari Dinas Kelautan dan Perikanan Sukabumi adalah data produksi hasil tangkapan, jumlah armada tahunan di PPI Cisolok, dan dari pengamatan langsung.

\section{Analisis data}

\section{Analysis Strength Weakness Opportunity} Threat (SWOT)

Strategi pengembangan fasilitasaktivitas kepelabuhanan perikanan di PPI Cisolok dilakukan melalui analisis matrik Internal Factor Analysis Summary (IFAS) dan External Factor Analysis Summary (EFAS). Analisis tersebut diperoleh berdasarkan hasil identifikasi terhadap faktor kekuatan dan kelemahan sebagai elemen yang menyusun faktor internal. Faktor eksternal didapatkan berdasarkan komponen yang menyusunnya yaitu berupa peluang dan ancaman (Pane 2017), yang berkaitan dengan pengembangan fasilitas-aktivitas kepelabuhanan perikanan di PPI Cisolok. Analisis SWOT dilakukan dengan tahapantahapan sebagai berikut:

1. Mengetahui faktor-faktor SWOT

a. Faktor internal: kekuatan dan kelemahan

$$
\text { Faktor-faktor internal }
$$

kemudian dianalisis, terlebih dahulu melakukan wawancara kepada pengelola pelabuhan, kepala PPI Cisolok, dan DKP. Kemudian disubstitusikan ke matrik IFAS. Faktor internal pada analisis SWOT adalah faktor-faktor yang ada dalam lingkup fasilitas-aktivitas PPI Cisolok. Faktor internal dapat dijadikan sebagai keunggulan dalam pengembangan fasilitas-aktivitas PPI Cisolok.

b. Faktor eksternal: ancaman dan peluang

Faktor eksternal terdiri dari peluang yang harus dimanfaatkan untuk mencapai tujuan yang diinginkan, sedangkan ancaman merupakan faktor yang harus dihindari dalam pengembangan dermaga dan kolam PPI Cisolok. Faktor-faktor eksternal kemudian dianalisis dengan melakukan wawancara kepada pengelola pelabuhan dan kepala PPI Cisolok. Hasil dari analisis dan pengamatan di lapangan kemudian disubstitusikan ke matrik EFAS.

2. Penentuan bobot faktor-faktor internal dan eksternal

Faktor-faktor yang telah dikemukakan di atas kemudian dianalisis secara deskriptif kualitatif menggunakan scoring method. Dilakukan pembuatan pertanyaanpertanyaan faktor-faktor internal dan eksternal strategi pengembangan fasilitas-aktivitas kepelabuhanan di PPI Cisolok, dan menentukan bobot.

3. Membuat kriteria untuk pengambilan keputusan (termasuk di dalamnya pembobotan):

- Perhitungan Jumlah Skor Maksimum (JSMax)

- Penentuan kriteria pengambilan keputusan (Tabel 1)

4. Pengambilan data jawaban responden atas pertanyaan-pertanyaan yang diajukan kepada responden; diperoleh Jumlah Skor (JS)

5. Pengolahan data dan pengambilan keputusan

- Membandingkan JS dengan JSMax untuk pertanyaan-pertanyaan.

6. Penentuan strategi pengembangan fasilitas-aktivitas kepelabuhanan perikanan di PPI Cisolok

- Membuat Matrik SWOT

- Menentukan strategi menurut skala prioritas

Setelah mendapatkan kriteria untuk pengambilan keputusan dari pertanyaanpertanyaan di atas, maka pertanyaan akan dimasukkan di komponen internal (kekuatan dan kelemahan) dan eksternal (peluang dan ancaman) terkait dengan strategi pengembangan fasilitas-aktivitas, kemudian diurutkan jumlah nilai untuk mendapatkan strategi prioritas pengembangan fasilitasaktivitas di PPI Cisolok. 
Tabel 1. Kriteria pengambilan keputusan data kualitatif dikuantitatifkan faktor-faktor internal dan eksternal strategi pengembangan fasilitas-aktivitas kepelabuhanan perikanan di PPI Cisolok

\begin{tabular}{|c|c|c|}
\hline \multicolumn{2}{|c|}{ Jumlah Skor Jawaban Responden JS terhadap JSMax } & \multirow{2}{*}{ Keputusan } \\
\hline Selang Kelas JS (\%) & Nilai Selang Kelas JS & \\
\hline $\mathrm{JS}<40 \%$ & $\mathrm{JS}<\ldots$ & Sangat kurang \\
\hline $40 \%<=\mathrm{JS}<55 \%$ & $\ldots<=\mathrm{JS}<\ldots$ & Kurang \\
\hline $55 \%<=\mathrm{JS}<70 \%$ & $\ldots<=\mathrm{JS}<\ldots$ & Cukup/Sedang \\
\hline $70 \%<=\mathrm{JS}<85 \%$ & $\ldots<=\mathrm{JS}<.$. & Baik \\
\hline $\mathrm{JS}>=85 \%$ & $\mathrm{JS}>=\ldots$ & Sangat baik \\
\hline
\end{tabular}

Keterangan:

JS : Jumlah skor jawaban responden

JSMax : Jumlah skor maksimum data kualitatif (dikuantitatifkan)

Sumber : Pane 2017

\section{HASIL DAN PEMBAHASAN}

Strategi pengembangan fasilitasaktivitas kepelabuhanan perikanan di PPI Cisolok di analisis menggunakan metode Strength Weakness Opportunity Threat (SWOT). Faktor internal (kekuatan dan kelemahan) dan faktor eksternal (peluang dan ancaman) pengembangan fasilitas dan aktivitas PPI Cisolok terdapat pada Tabel 2.

Penjelasan mengenai faktor-faktor internal (kekuatan dan kelemahan) dan faktor eksternal (peluang dan ancaman) terkait pengembangan fasilitas-aktivitas di PPI Cisolok adalah sebagai berikut:

\section{Kekuatan (Strengths)}

1. Tingginya aktivitas pendaratan ikan hasil tangkapan

Aktivitas pendaratan ikan hasil tangkapan di PPI Cisolok menghasilkan rata-rata 2,6 ton per hari. Menurut PER.08/MEN/2012, aktivitas pendaratan ikan hasil tangkapan dan pemasaran hasil perikanan untuk kelas PPI rata-rata 2 ton per hari.

2. Banyaknya jumlah perahu di PPI Cisolok

Jumlah Perahu Motor Tempel PPI Cisolok tahun 2016 yaitu 256 unit, artinya jumlah perahu tersebut adalah banyak untuk skala kelas PPI.

3. Adanya keinginan pihak pengelola PPI Cisolok dan Dinas Kelautan dan Perikanan Kabupaten Sukabumi untuk melakukan pengembangan armada Kapal Motor (KM), pada tahap awal untuk KM berukuran $\leq 10 \mathrm{GT}$. Saat ini armada penangkapan yang ada baru berupa Perahu Motor Tempel (PMT)
4. Lahan pelabuhan yang tersedia adalah cukup untuk pengembangan dermaga pendaratan

Pangkalan Pendaratan Ikan Cisolok memiliki luas lahan pelabuhan sekitar 7 ha atau $70.000 \mathrm{~m}^{2}$, luas lahan tersebut melebihi luas lahan yang seharusnya pada kelas PPI, yaitu sekurang-kurangnya 1 ha menurut PER.08/MEN/2012.

Menurut PER.08/MEN/2012, panjang dermaga untuk kelas PPI sekurang kurangnya $50 \mathrm{~m}$. Pangkalan Pendaratan Ikan Cisolok memiliki panjang dermaga $240 \mathrm{~m}$, tetapi dalam kondisi yang rusak, dan tertutup lahan sedimen pasir karena adanya kolam pelabuhan yang mengalami sedimentasi.

5. Lahan pelabuhan yang tersedia adalah cukup untuk pengembangan kolam pelabuhan

Luas kolam Pelabuhan di PPI Cisolok saat ini sekitar $31.200 \mathrm{~m}^{2}$ dan jumlah perahu maksimum yang berlabuh adalah 256 perahu. Menurut PER.08/MEN/2012, kolam pelabuhan untuk kelas PPI mampu menampung kapal perikanan sekurang-kurangnya 15 unit atau jumlah keseluruhan sekurang-kurangnya 75 GT, kemudian memiliki fasilitas tambat labuh untuk kapal perikanan berukuran sekurangkurangnya 5 GT.

6. Adanyarencana program pengembangan fasilitas pokok PPI Cisolok (dermaga dan kolam pelabuhan)

Berdasarkan hasil wawancara yang telah dilakukan, pembangunan 
dermaga dan kolam pelabuhan telah ada pada tahun 2001-2005. Selanjutnya dikarenakan adanya kerusakan dermaga dan kolam pelabuhan, serta adanya sedimentasi, maka kemudian pernah direncanakan perbaikan pada tahun 2014, akan tetapi tidak jadi dilakukan karena terkendala anggaran. Pihak pengelola pelabuhan pemerintah Kabupaten Sukabumi dan konsultan telah membuat proposal, dan rencana penganggarannya akan diajukan kepada pemerintah Provinsi Jawa Barat dan Pemerintah Pusat (Kementerian Kelautan dan Perikanan).

7. Adanya aktivitas pendaratan ikan hasil tangkapan

Berdasarkan hasil pengamatan dan wawancara, aktivitas pendaratan ikan hasil tangkapan di PPI Cisolok dilakukan setiap hari, kecuali pada hari Jum'at para nelayan tidak melakukan operasi penangkapan. Hampir setiap hari aktivitas pendaratan ikan di PPI Cisolok berlangsung ramai, pendaratan ikan biasanya dilakukan pada pagi hari.

\section{Kelemahan (Weakness)}

1. Adanya pendangkalan alur pelayaran dan kolam pelabuhan

Berdasarkan hasil pengamatan dan wawancara, kolam pelabuhan dan alur pelayaran PPI Cisolok saat ini kondisinya tertutup pasir. Sebagaimana dikemukakan sebelumnya, hal ini terjadi dikarenakan kesalahan pembangunan arah dan posisi breakwater.

2. Rusaknya breakwater dan kesalahan pembangunannya

Pembangunan breakwater sudah hampir selesai sejak tahun 2004, tetapi karena gelombang besar menyebabkan breakwater tersebut rusak. Selanjutnya pada tahun 2007 dilakukan perbaikan pertama breakwater dan pengerukan, karena ombak dan gelombang besar mengakibatkan kerusakan breakwater kembali. Perbaikan breakwater yang kedua yaitu pada tahun 2009, juga tetap tidak mampu menahan hempasan ombak dan gelombang sehingga rusak sampai saat ini.

3. Kecilnya ukuran armada penangkapan ikan yang ada

Ukuran armada perahu yang digunakan di PPI Cisolok masih relatif kecil, yaitu <5GT. Ukuran perahu yang relatif kecil tersebut berpengaruh pada jangkauan operasi penangkapan ikan.
Nelayan di PPI Cisolok melakukan operasi penangkapan one day fishing, karena dekatnya fishing ground (di sekitar teluk palabuhanratu) dan ukuran perahu yang relatif kecil. Ukuran perahu di PPI Cisolok 11x2x3 meter.

4. Ada dermaga pendaratan ikan tetapi tidak dapat dimanfaatkan oleh nelayan Peraturan Menteri Kelautan dan Perikanan nomor 8 tahun 2012 menyebutkan bahwa Pelabuhan Perikanan tipe D (PPI) diharuskan memiliki dermaga dengan panjang sekurang-kurangnya $50 \mathrm{~m}$. Berdasarkan hasil pengamatan dan wawancara, PPI Cisolok memiliki dermaga yang cukup panjang yaitu $240 \mathrm{~m}$, namun dermaga dalam kondisi yang rusak, dan tertutup oleh pasir, sehingga nelayan tidak dapat bertambat dan berlabuh di dermaga dengan nyaman. Hasil wawancara dengan nelayan PPI Cisolok mengatakan bahwa, hampir tiap tahun ada perahu Cisolok yang terbawa ombak besar, karena tempat berlabuh/bertambat saat ini tidak aman, dan rawan jika sedang terjadi ombak besar.

5. Ada kolam pelabuhan tetapi tidak dapat dimanfaatkan oleh nelayan

Fasilitas pokok (dermaga dan kolam pelabuhan) yang tersedia di PPI Cisolok belum memenuhi kriteria yang tercantum dalam peraturan Menteri Kelautan dan Perikanan nomor 8 tahun 2012 tentang pelabuhan perikanan. Kondisi kolam pelabuhan di PPI Cisolok tidak dapat dimanfaatkan oleh nelayan, karena telah tertutup pasir.

6. Belum adanya pelayanan pengisian bahan bakar melaut

Jasa pelayanan bahan bakar melaut belum disediakan di PPI Cisolok saat ini, untuk kebutuhan bahan bakar melaut, nelayan membeli sendiri dari luar pelabuhan. Penyediaan fasilitas bahan bakar melaut di PPI Cisolok seharusnya dilakukan, karena keberadaan fasilitas tersebut dapat memudahkan nelayan dalam memperoleh bahan bakar sebelum melaut, dan juga meringankan beban biaya nelayan karena mendapat subsidi dari pemerintah. Pembelian bahan bakar melaut yang dilakukan nelayan Cisolok di luar pelabuhan, akan menyebabkan nelayan mengeluarkan biaya tambahan seperti biaya pengangkutan bahan bakar. 
Tabel 2. Faktor internal dan faktor eksternal PPI Cisolok

\begin{tabular}{|c|c|c|}
\hline \multicolumn{2}{|r|}{ Kekuatan (Strengths) } & Kelemahan (Weakness) \\
\hline 1 & $\begin{array}{l}\text { Tingginya aktivitas pendaratan ikan hasil } \\
\text { tangkapan }\end{array}$ & $\begin{array}{l}\text { Adanya pendangkalan alur pelayaran } \\
\text { dan kolam pelabuhan }\end{array}$ \\
\hline 2 & Banyaknya jumlah perahu di PPI Cisolok & $\begin{array}{l}2 \text { Rusaknya breakwater dan kesalahan } \\
\text { pembangunannya }\end{array}$ \\
\hline 3 & $\begin{array}{l}\text { Adanya keinginan pihak pengelola } \\
\text { PPI Cisolok dan Dinas Kelautan dan } \\
\text { Perikanan Kabupaten Sukabumi untuk } \\
\text { melakukan pengembangan armada KM }\end{array}$ & $\begin{array}{l}3 \text { Kecilnya ukuran armada penangkap } \\
\text { ikan yang ada }\end{array}$ \\
\hline 4 & $\begin{array}{l}\text { Lahan pelabuhan yang tersedia adalah } \\
\text { cukup untuk pengembangan dermaga } \\
\text { pendaratan }\end{array}$ & $\begin{array}{l}4 \text { Ada dermaga pendaratan ikan tetapi } \\
\text { tidak dapat dimanfaatkan oleh nelayan }\end{array}$ \\
\hline 5 & $\begin{array}{l}\text { Lahan pelabuhan yang tersedia adalah } \\
\text { cukup untuk pengembangan kolam } \\
\text { pelabuhan }\end{array}$ & $\begin{array}{l}5 \text { Ada kolam pelabuhan tetapi tidak dapat } \\
\text { dimanfaatkan oleh nelayan }\end{array}$ \\
\hline 6 & $\begin{array}{l}\text { Adanya rencana program pengembangan } \\
\text { fasilitas pokok PPI Cisolok (dermaga dan } \\
\text { kolam pelabuhan) }\end{array}$ & $\begin{array}{l}6 \text { Belum adanya pelayanan pengisian } \\
\text { bahan bakar melaut }\end{array}$ \\
\hline 7 & $\begin{array}{l}\text { Adanya aktivitas pendaratan ikan hasil } \\
\text { tangkapan }\end{array}$ & $\begin{array}{l}7 \text { Belum adanya pelayanan tambat labuh } \\
\text { armada penangkapan ikan di PPI } \\
\text { Cisolok }\end{array}$ \\
\hline & Peluang (Opportunities) & Ancaman (Threats) \\
\hline 1 & $\begin{array}{l}\text { Tingginya potensi sumberdaya ikan di } \\
\text { pantai selatan (WPP Samudera Hindia) }\end{array}$ & $\begin{array}{l}\text { Kondisi cuaca/musim belum responsif } \\
\text { terhadap armada PMT di PPI Cisolok }\end{array}$ \\
\hline 2 & $\begin{array}{l}\text { Adanya petugas ad hoc dari luar } \\
\text { pelabuhan yang menangani hal-hal yang } \\
\text { berkaitan dengan pengembangan fasilitas } \\
\text { pokok }\end{array}$ & $\begin{array}{lll}2 & \text { Adanya nelayan Cisolok yang } \\
\text { mendaratkan dan memasarkan } & \text { ikan } \\
\text { langsung ke PPN Palabuhanratu } & \end{array}$ \\
\hline 3 & $\begin{array}{l}\text { Kedekatan PPI Cisolok ke lokasi-lokasi } \\
\text { pemasaran ikan }\end{array}$ & $\begin{array}{l}3 \text { Belum ada anggaran pengembangan } \\
\text { PPI Cisolok yang mencukupi }\end{array}$ \\
\hline 4 & $\begin{array}{l}\text { Daerah Cisolok termasuk daerah wisata } \\
\text { bahari potensial yang sedang berkembang }\end{array}$ & \\
\hline 5 & $\begin{array}{l}\text { Dukungan Dinas Kelautan dan Perikanan } \\
\text { Kabupaten Sukabumi }\end{array}$ & \\
\hline 6 & $\begin{array}{l}\text { Adanya dukungan/keinginan nelayan, } \\
\text { pedagang, pengolah ikan untuk } \\
\text { pengembangan PPI Cisolok }\end{array}$ & \\
\hline 7 & $\begin{array}{l}\text { Adanya peluang yang positif anggaran } \\
\text { dana untuk pengembangan PPI Cisolok }\end{array}$ & \\
\hline
\end{tabular}

7. Belum adanya pelayanan tambat labuh armada penangkapan ikan di PPI Cisolok

Berdasarkan pengamatan di lapang dan wawancara, di PPI Cisolok belum terdapat jasa pelayanan tambat dan labuh armada penangkapan ikan, karena dermaga dan kolam pelabuhan yang saat ini dalam kondisi tertimbun pasir dan rusak sehingga tidak terdapat pelayanan tambat labuh perahu.

\section{Peluang (Opportunity)}

1. Tingginya potensi sumberdaya ikan di pantai selatan (WPP Samudera Hindia)

Pangkalan Pendaratan Ikan Cisolok terletak di Teluk Palabuhanratu yang terdapat di Samudera Hindia termasuk dalam WPP 573. Potensi sumber daya ikan di Samudera Hindia (WPP 573) tahun 2016 yaitu 1.267.540 ton (KKP 2018), artinya nelayan di PPI Cisolok mempunyai kesempatan untuk 
dapat memanfaatkan potensi sumber daya ikan di WPP 573 tersebut.

2. Adanya petugas ad hoc dari luar pelabuhan yang menangani hal-hal yang berkaitan dengan pengembangan fasilitas pokok. Berdasarkan hasil wawancara, telah terdapat kerjasama antara pihak PPI Cisolok dengan pihak konsultan dari luar pelabuhan yang mengerti tentang kepelabuhanan perikanan untuk pengembangan fasilitas pokok (dermaga, kolam pelabuhan, dan breakwater). Pihak konsultan siap bekerjasama menangani pengembangan fasilitas pokok kepelabuhanan di PPI Cisolok.

3. Kedekatan PPI Cisolok ke lokasi-lokasi pemasaran ikan

Lokasi-lokasi pemasaran ikan yaitu di seluruh kecamatan yang ada di kabupaten Sukabumi adalah mudah dijangkau dari PPI Cisolok. Lokasi PPI Cisolok dekat dari Pelabuhan Perikanan Nusantara Palabuhanratu (PPNPr). Kondisi jalan pemasaran ikan sebagian besar adalah aspal, dapat dilalui oleh kendaraan beroda empat. Hal tersebut disebabkan karena adanya program pemerintah dalam membangun jalan di Kecamatan Cisolok. Jarak terdekat antara PPI Cisolok dengan kecamatan disekitarnya, yaitu Kecamatan Palabuhanratu adalah $16 \mathrm{~km}$, dan jarak terjauh yaitu dari PPI Cisolok ke Kecamatan Cidolog adalah $115 \mathrm{~km}$.

4. Daerah Cisolok termasuk daerah wisata bahari potensial yang sedang berkembang

Salah satu daya tarik wisata bahari saat ini yang sedang berkembang yang dapat ditemukan di Kabupaten Sukabumi adalah di Kecamatan Cisolok. Kawasan wisata pantai di Kecamatan Cisolok berada di Desa Karangpapak, Desa Cisolok dan Desa Pasir baru. Kawasan tersebut juga merupakan kawasan alami yang dimanfaatkan baik sebagai tempat wisata pantai maupun tempat olahraga surfing (BPS Kabupaten Sukabumi 2018). Hal ini didukung dengan pernyataan Indrayani (2017), PPI Cisolok merupakan salah satu PPI yang paling ramai dan banyak dikunjungi oleh para pembeli dibandingkan PPI lain di Sukabumi, karena PPI Cisolok letaknya strategis dekat dengan Pelabuhan Perikanan
Nusantara Palabuhanratu dan menyatu dengan kegiatan pariwisata. Banyak wisatawan dari berbagai daerah yang datang untuk membeli produk ikan hasil tangkapan di PPI Cisolok.

5. Dukungan Dinas Kelautan dan Perikanan Kabupaten Sukabumi

Berdasarkan hasil wawancara, Dinas Kelautan dan Perikanan (DKP) Sukabumi sangat mendukung pengembangan fasilitas-aktivitas PPI Cisolok. Menurut pihak Dinas Kelautan dan Perikanan Kabupaten Sukabumi, pembangunan dermaga PPI Cisolok, dahulunya merupakan pembangunan dermaga yang gagal di pelabuhan perikanan Kabupaten Sukabumi. Pembangunan dermaga sudah dimulai sejak 2001. Pembangunan dermaga tersebut bertujuan untuk memberikan kenyamanan nelayan PPI Cisolok dalam mendaratkan hasil tangkapannya, namun sampai saat ini dermaga dan kolam di PPI Cisolok tidak dapat dimanfaatkan, karena kondisi yang rusak dan tertutup sedimen pasir serta salah arah/posisi breakwater.

6. Adanya dukungan/keinginan nelayan, pedagang, pengolah ikan untuk pengembangan PPI Cisolok

Berdasarkan hasil wawancara terhadap nelayan, pedagang dan pengolah ikan, mereka sangat mendukung dan mengharapkan pembangunan/pengembangan fasilitas PPI Cisolok dapat cepat diselesaikan. Nelayan Cisolok menginginkan, mereka dapat mendaratkan ikan di PPI Cisolok dan dapat bertambat labuh dengan aman. Pedagang ikan dan pengolah ikan berharap dapat meningkatkan aktivitas mereka di PPI Cisolok.

7. Adanya peluang yang positif anggaran dana untuk pengembangan PPI Cisolok

Berdasarkan hasil wawancara dengan Pemerintah Provinsi Jawa Barat saat ini sudah menyetujui dan bersedia memberikan anggaran sebesar 50 miliar rupiah. Demikian pula, pada saat ini Gubernur Jawa Barat sudah mengajukan surat ke Kementerian Kelautan dan Perikanan (KKP), untuk pengajuan tambahan anggaran pengembangan PPI Cisolok. Menurut DKP Sukabumi anggaran dana untuk pengembangan PPI Cisolok sekitar 136 miliar rupiah. 


\section{Ancaman (Threat)}

1. Kondisi cuaca/musim belum responsif terhadap armada PMT di PPI Cisolok

Perairan Teluk Palabuhanratu sering mengalami gelombang besar pada Musim Barat. Gelombang tertinggi terjadi pada periode bulan Desember sampai Februari (Musim Barat), ketinggian gelombang mencapai 1,5-2 $\mathrm{m}$, sedangkan pada bulan lainnya tinggi gelombang yang tercatat kurang dari 1,5 m. Perairan Teluk Palabuhanratu dan sekitarnya pada saat Musim Barat memiliki pola gerak arus dari arah barat menyusuri pantai menuju teluk dengan kecepatan 11,6-21,7 cm/detik, disertai curah hujan bulanan yang tinggi mencapai 272-351 $\mathrm{mm}$, sementara pada Musim Timur arus bergerak menuju teluk dari arah barat dengan kecepatan 13,0-16,1 cm/detik, disertai curah hujan bulanan yang rendah yaitu 69-164 mm (DKP Sukabumi 2011). Oleh karena itu saat Musim Barat atau musim penghujan datang, hanya sedikit nelayan Cisolok yang melakukan operasi penangkapan ikan, karena baru memiliki armada kategori PMT.

2. Adanya nelayan Cisolok yang mendaratkan dan memasarkan ikan langsung ke PPN Palabuhanratu

Berdasarkan hasil pengamatan dan wawancara, nelayan Cisolok tidak dapat mendaratkan ikan di PPI Cisolok yang tidak aman apabila tambat labuh di sana, maka terdapat sebagian nelayan Cisolok yang menggunakan perahu payang mendaratkan dan memasarkan ikan langsung ke PPN Palabuhanratu. Terdapat sekitar 2030 perahu yang mendaratkan dan memasarkan ikan langsung ke PPN Palabuhanratu. Nelayan tersebut melaut pada pagi hari dari dermaga PPN Palabuhanratu, kemudian tambat labuh dan mendaratkan hasil tangkapan di PPN Palabuhanratu pada sore hari. Tidak ada pelelangan ikan di TPI PPN Palabuhanratu, sehingga nelayan langsung menjual dan menimbang berat ikan hasil tangkapan kepada pedagang pembeli di dermaga pendaratan PPN Palabuhanratu (Pane 2010). Setelah itu nelayan Cisolok langsung pulang ke Cisolok menggunakan angkot atau mobil bak, dengan membawa peralatan dan alat tangkap.
3. Belum ada anggaran pengembangan PPI Cisolok yang mencukupi

Berdasarkan hasil wawancara, diketahui belum ada anggaran yang cukup untuk pengembangan fasilitasaktivitas PPI Cisolok. Pada tahun 2015, anggaran yang disetujui oleh Gubernur dan Dinas Perikanan dan Kelautan Provinsi Jawa Barat hanya 50 miliar rupiah. Menurut pihak konsultan dana tersebut tidak mencukupi untuk pengembangan fasilitas pokok di PPI Cisolok, sehingga pengembangan fasilitas (dermaga, kolam pelabuhan, dan breakwater) di PPI Cisolok tidak jadi dilakukan.

\section{Faktor-faktor internal pengembangan fasilitas-aktivitas PPI Cisolok}

Faktor-faktor internal terkait pengembangan fasilitas-aktivitas di PPI Cisolok diidentifikasi, untuk mengetahui faktor-faktor yang dijadikan kekuatan (strength) dan kelemahan (weakness) dalam penentuan pengembangan fasilitas pokok (dermaga dan kolam pelabuhan) di PPI Cisolok. Faktor internal yang mempengaruhi pengembangan fasilitasaktivitas kepelabuhanan perikanan di PPI Cisolok tahun 2017 terdapat pada Tabel 3.

Berdasarkan matrik IFAS (Tabel 3) dapat diketahui faktor kekuatan mempunyai jumlah skor sebesar 220,0 yang termasuk dalam kriteria sangat baik, berada pada selang pengambilan keputusan $>=85 \%(>200,6)$, artinya PPI Cisolok dapat merespon sangat baik dengan kekuatan yang ada. Kemudian faktor kelemahan mempunyai jumlah skor sebesar 108 yang termasuk dalam kriteria kurang, berada pada selang pengambilan keputusan $55 \%<=\mathrm{JS}<70 \% \quad(105,6<\mathrm{JS}>134,4) . \quad$ Dilihat dari jumlah nilai faktor kekuatan dan faktor kelemahan dapat diketahui faktor kekuatan lebih dominan daripada faktor kelemahan. Kekuatan utama pengembangan fasilitasaktivitas kepelabuhanan perikanan di PPI Cisolok terletak pada tingginya aktivitas pendaratan ikan hasil tangkapan dan banyaknya jumlah perahu di PPI Cisolok dengan jumlah skor 40,0. Kemudian beberapa kelemahan pengembangan fasilitas-aktivitas kepelabuhanan perikanan di PPI Cisolok yaitu terdapat fasilitas dermaga dan kolam pelabuhan, tetapi tidak dapat dimanfaatkan nelayan Cisolok 
sebagaimana fungsi fasilitas seharusnya. Hal ini sesuai dengan pernyataan Rosalia et al. (2018) PPI Cisolok memiliki fasilitas dermaga dan kolam pelabuhan yang tidak dapat digunakan karena kondisi fasilitas yang rusak dan adanya proses sedimentasi yang cukup besar, sehingga nelayan Cisolok tidak dapat melakukan aktivitas pendaratan ikan dengan nyaman dan aman. Kelemahan pengembangan fasilitas aktivitas kepelabuhanan perikanan di PPI Cisolok yang lainnya yaitu belum adanya pelayanan tambat labuh armada penangkapan ikan, sedangkan menurut Hutapea et al. (2017) kegiatan tambat labuh merupakan kegiatan yang paling tinggi aktivitasnya di Pelabuhan Perikanan (PP), sehingga perlu penyediaan tempat tambat labuh di suatu PP.

\section{Faktor-faktor eksternal pengembangan fasilitas-aktivitas PPI Cisolok}

Faktor-faktor eksternal terkait pengembangan fasilitas-aktivitas di PPI Cisolok diidentifikasi, untuk mengetahui faktor-faktor yang dijadikan peluang (Opportunity) dan ancaman (Threath) dalam penentuan pengembanan fasilitas pokok (dermaga dan kolam pelabuhan) di PPI Cisolok. Faktor eksternal yang mempengaruhi pengembangan fasilitasaktivitas kepelabuhanan perikanan di PPI Cisolok tahun 2017 terdapat pada Tabel 4.

Tabel 3. Matrik IFAS strategi pengembangan fasilitas-aktivitas kepelabuhanan perikanan di PPI Cisolok tahun 2017

\begin{tabular}{|c|c|c|c|c|}
\hline No & Faktor-faktor internal & Bobot & Rating & Skor \\
\hline & Kekuatan (Strengths) & & & \\
\hline 1 & $\begin{array}{l}\text { Tingginya aktivitas pendaratan ikan hasil } \\
\text { tangkapan }\end{array}$ & 2,0 & 4 & 40,0 \\
\hline 2 & Banyaknya jumlah perahu di PPI Cisolok & 2,0 & 4 & 40,0 \\
\hline 3 & $\begin{array}{l}\text { Adanya keinginan pihak pengelola PPI Cisolok } \\
\text { dan Dinas Kelautan dan Perikanan Kabupaten } \\
\text { Sukabumi untuk melakukan pengembangan } \\
\text { armada KM }\end{array}$ & 2,0 & 2 & 24,0 \\
\hline 4 & $\begin{array}{l}\text { Lahan pelabuhan yang tersedia adalah cukup } \\
\text { untuk pengembangan dermaga pendaratan }\end{array}$ & 2,7 & 2 & 32,0 \\
\hline 5 & $\begin{array}{l}\text { Lahan pelabuhan yang tersedia adalah cukup } \\
\text { untuk pengembangan kolam pelabuhan }\end{array}$ & 2,7 & 2 & 32,0 \\
\hline 6 & $\begin{array}{l}\text { Adanya rencana program pengembangan fasilitas } \\
\text { pokok PPI Cisolok (dermaga dan kolam pelabuhan) }\end{array}$ & 2,0 & 2 & 24,0 \\
\hline \multirow[t]{3}{*}{7} & Adanya aktivitas pendaratan ikan hasil tangkapan & 2,3 & 2 & 28,0 \\
\hline & Jumlah Skor (JS) & 15,7 & - & 220,0 \\
\hline & Kelemahan (Weakness) & & & \\
\hline 1 & $\begin{array}{l}\text { Adanya pendangkalan alur pelayaran dan kolam } \\
\text { pelabuhan }\end{array}$ & 2,0 & 2 & 24 \\
\hline 2 & $\begin{array}{l}\text { Rusaknya breakwater dan kesalahan } \\
\text { pembangunannya }\end{array}$ & 2,0 & 2 & 24 \\
\hline 3 & $\begin{array}{l}\text { Kecilnya ukuran armada penangkap ikan yang } \\
\text { ada }\end{array}$ & 2,0 & 1 & 12 \\
\hline 4 & $\begin{array}{l}\text { Ada dermaga pendaratan ikan tetapi tidak dapat } \\
\text { dimanfaatkan oleh nelayan }\end{array}$ & 2,0 & 1 & 12 \\
\hline 5 & $\begin{array}{l}\text { Ada kolam pelabuhan tetapi tidak dapat } \\
\text { dimanfaatkan oleh nelayan }\end{array}$ & 2,0 & 1 & 12 \\
\hline 6 & $\begin{array}{l}\text { Belum adanya pelayanan pengisian bahan bakar } \\
\text { melaut }\end{array}$ & 2,0 & 1 & 12 \\
\hline \multirow[t]{2}{*}{7} & $\begin{array}{l}\text { Belum adanya pelayanan tambat labuh armada } \\
\text { penangkapan ikan di PPI Cisolok }\end{array}$ & 2,0 & 1 & 12 \\
\hline & Jumlah Skor (JS) & 14,0 & - & 108,0 \\
\hline
\end{tabular}


Tabel 4. Matrik EFAS strategi pengembangan fasilitas-aktivitas kepelabuhanan perikanan di PPI Cisolok tahun 2017

\begin{tabular}{|c|c|c|c|c|}
\hline No & Faktor-faktor enternal & Bobot & Rating & Skor \\
\hline & Peluang (Opportunities) & & & \\
\hline 1 & $\begin{array}{l}\text { Tingginya potensi sumberdaya ikan di pantai } \\
\text { selatan (WPP Samudera Hindia) }\end{array}$ & 1,8 & 4 & 44,0 \\
\hline 2 & $\begin{array}{l}\text { Adanya petugas ad hoc dari luar pelabuhan } \\
\text { yang menangani hal-hal yang berkaitan dengan } \\
\text { pengembangan fasilitas pokok }\end{array}$ & 2,2 & 2 & 26,0 \\
\hline 3 & $\begin{array}{l}\text { Kedekatan PPI Cisolok ke lokasi-lokasi pemasaran } \\
\text { ikan }\end{array}$ & 2,0 & 2 & 24,0 \\
\hline 4 & $\begin{array}{l}\text { Daerah Cisolok termasuk daerah wisata bahari } \\
\text { potensial yang sedang berkembang }\end{array}$ & 2,0 & 2 & 24,0 \\
\hline 5 & $\begin{array}{l}\text { Dukungan Dinas Kelautan dan Perikanan } \\
\text { Kabupaten Sukabumi }\end{array}$ & 2,0 & 2 & 24,0 \\
\hline 6 & $\begin{array}{l}\text { Adanya dukungan/keinginan nelayan, pedagang, } \\
\text { pengolah ikan untuk pengembangan PPI Cisolok }\end{array}$ & 2,0 & 2 & 24,0 \\
\hline \multirow[t]{3}{*}{7} & $\begin{array}{l}\text { Adanya peluang yang positif anggaran dana untuk } \\
\text { pengembangan PPI Cisolok }\end{array}$ & 2,0 & 2 & 20,0 \\
\hline & Jumlah Skor (JS) & 14,0 & & 186,0 \\
\hline & Ancaman (Threats) & & & \\
\hline 1 & $\begin{array}{l}\text { Kondisi cuaca/musim belum responsif terhadap } \\
\text { armada PMT di PPI Cisolok }\end{array}$ & 2,5 & 1 & 30,0 \\
\hline 2 & $\begin{array}{l}\text { Adanya nelayan Cisolok yang mendaratkan dan } \\
\text { memasarkan ikan langsung ke PPN Palabuhanratu }\end{array}$ & 2,5 & 2 & 15,0 \\
\hline \multirow[t]{2}{*}{3} & $\begin{array}{l}\text { Belum ada anggaran pengembangan PPI Cisolok } \\
\text { yang mencukupi }\end{array}$ & 2,0 & 1 & 12,0 \\
\hline & Jumlah Skor (JS) & 7,0 & - & 57,0 \\
\hline
\end{tabular}

Berdasarkan matrik EFAS (Tabel 4) dapat diketahui faktor peluang mempunyai jumlah skor sebesar 186,0 yang termasuk dalam kriteria sangat baik berada pada selang pengambilan keputusan $>=85 \% \quad(>181,9)$, artinya PPI Cisolok dapat merespon dengan sangat baik peluang yang ada. Kemudian faktor ancaman mempunyai jumlah skor sebesar 57,0 yang termasuk dalam kriteria cukup/sedang, berada pada selang pengambilan keputusan $55 \%<=\mathrm{JS}<70 \%$ $(46,2<\mathrm{JS}>58,8)$. Dilihat dari jumlah skor faktor peluang dan faktor ancaman dapat diketahui faktor peluang lebih dominan daripada faktor ancaman. Peluang utama pengembangan fasilitas-aktivitas kepelabuhanan perikanan di PPI Cisolok terletak pada tingginya potensi sumberdaya ikan di pantai selatan (WPP Samudera Hindia), dengan jumlah skor 44,00. Kemudian ancaman utama pengembangan fasilitas-aktivitas kepelabuhanan perikanan di PPI Cisolok terletak pada kondisi cuaca/ musim belum responsif terhadap armada
PMT, dengan jumlah skor 30. Matrik SWOT strategi pengembangan fasilitas-aktivitas kepelabuhanan perikanan di PPI Cisolok Kabupaten Sukabumi tahun 2017 terdapat pada Tabel 5 .

Fasilitas pokok (dermaga pendaratan dan kolam pelabuhan) yang tersedia di PPI Cisolok belum memenuhi kriteria yang tercantum dalam peraturan Menteri Kelautan dan Perikanan nomor 8 tahun 2012 tentang Kepelabuhanan Perikanan. Kondisi kolam pelabuhan di PPI Cisolok tidak dapat dimanfaatkan oleh nelayan, karena telah tertutup pasir. Banyak perahu yang berlabuh di luar kolam PPI Cisolok, ketika ada arus dan gelombang besar. Fasilitas pokok merupakan fasilitas yang harus ada dan sangat penting yang harus dimiliki oleh suatu pelabuhan perikanan. Apabila dermaga di PPI Cisolok dikelola dengan baik maka akan dapat meningkatkan produksi hasil tangkapan karena akan banyak perahu memilih mendaratkan hasil tangkapannya ke PPI Cisolok. 
Tabel 5. Matrik SWOT strategi pengembangan fasilitas-aktivitas kepelabuhanan perikanan di PPI Cisolok Kabupaten Sukabumi tahun 2017

\begin{tabular}{|c|c|c|c|}
\hline \multirow{8}{*}{\multicolumn{2}{|c|}{ IFAS }} & STRENGTHS (S) & WEAKNESS (W) \\
\hline & & $\begin{array}{l}\text { 1. Tingginya aktivitas } \\
\text { pendaratan ikan hasil } \\
\text { tangkapan (S1) }\end{array}$ & $\begin{array}{l}\text { 1. Adanya pendangkalan } \\
\text { alur pelayaran dan } \\
\text { kolam pelabuhan (W1) }\end{array}$ \\
\hline & & $\begin{array}{l}\text { 2. Banyaknya jumlah } \\
\text { perahu di PPI Cisolok (S2) }\end{array}$ & $\begin{array}{l}\text { 2. Rusaknya breakwater } \\
\text { dan kesalahan } \\
\text { pembangunannya (W2) }\end{array}$ \\
\hline & & $\begin{array}{l}\text { 3. Lahan pelabuhan yang } \\
\text { tersedia adalah cukup } \\
\text { untuk pengembangan } \\
\text { dermaga pendaratan (S3) }\end{array}$ & $\begin{array}{l}\text { 3. Kecilnya ukuran armada } \\
\text { penangkap ikan di PPI } \\
\text { Cisolok (W3) }\end{array}$ \\
\hline & & $\begin{array}{l}\text { 4ahan pelabuhan yang } \\
\text { tersedia adalah cukup } \\
\text { untuk pengembangan } \\
\text { kolam pelabuhan (S4) }\end{array}$ & $\begin{array}{l}\text { 4. Ada dermaga pendaratan } \\
\text { ikan tetapi tidak dapat } \\
\text { dimanfaatkan oleh } \\
\text { nelayan (W4) }\end{array}$ \\
\hline & & $\begin{array}{l}\text { 5. Adanya keinginan pihak } \\
\text { pengelola PPI dan Dinas } \\
\text { Kelautan dan Perikanan } \\
\text { Kabupaten Sukabumi } \\
\text { untuk melakukan } \\
\text { pengembangan armada } \\
\text { KM (S5) }\end{array}$ & $\begin{array}{l}\text { 5. Ada kolam pelabuhan } \\
\text { tetapi tidak dapat } \\
\text { dimanfaatkan oleh } \\
\text { nelayan (W5) }\end{array}$ \\
\hline & & $\begin{array}{l}\text { 6. Adanya rencana program } \\
\text { pengembangan fasilitas } \\
\text { pokok PPI Cisolok } \\
\text { (dermaga dan kolam } \\
\text { pelabuhan) (S6) }\end{array}$ & $\begin{array}{l}\text { 6. Belum adanya } \\
\text { pelayanan pengisian } \\
\text { bahan bakar melaut } \\
\text { (W6) }\end{array}$ \\
\hline & & $\begin{array}{l}\text { 7. Adanya aktivitas } \\
\text { pendaratan ikan hasil } \\
\text { tangkapan (S7) }\end{array}$ & $\begin{array}{l}\text { 7. Belum adanya } \\
\text { pelayanan tambat labuh } \\
\text { armada (W7) }\end{array}$ \\
\hline \multicolumn{4}{|c|}{ EFAS } \\
\hline & OPPORTUNITY (O) & STRATEGI (SO) & STRATEGI (WO) \\
\hline & $\begin{array}{l}\text { Tingginya potensi } \\
\text { sumberdaya ikan di } \\
\text { pantai selatan (WPP } \\
\text { Samudera Hindia) (O1) }\end{array}$ & $\begin{array}{l}\text { Melakukan pembangunan } \\
\text { fasilitas pokok } \\
\text { (dermaga dan kolam } \\
\text { pelabuhan) dan } \\
\text { meningkatkan jumlah } \\
\text { dan ukuran armada } \\
\text { penangkapan ikan untuk } \\
\text { memanfaatkan tingginya } \\
\text { potensi sumberdaya } \\
\text { Ikan di WPP 573 } \\
\text { (S1,S2,S3,S4,O1) }\end{array}$ & $\begin{array}{l}\text { Melakukan perbaikan } \\
\text { breakwater dengan } \\
\text { menambah di sebelah } \\
\text { kiri dan kanan } \\
\text { pelabuhan, kemudian } \\
\text { melakukan pengerukan } \\
\text { sedimentasi, sehingga } \\
\text { perahu dapat keluar/ } \\
\text { masuk pelabuhan } \\
\text { dengan aman } \\
\text { (W1,W2,O1) }\end{array}$ \\
\hline & $\begin{array}{l}\text { Adanya petugas ad hoc } \\
\text { dari luar pelabuhan } \\
\text { yang menangani hal- } \\
\text { hal yang berkaitan } \\
\text { dengan pengembangan } \\
\text { fasilitas pokok }(\mathrm{O} 2)\end{array}$ & $\begin{array}{l}\text { - Menjalin kerjasama } \\
\text { dengan para pengusaha } \\
\text { untuk terlibat dalam } \\
\text { kegiatan perencanaan } \\
\text { dan pengembangan PPI } \\
\text { Cisolok }(\mathrm{S} 5, \mathrm{~S} 6, \mathrm{~S} 7, \mathrm{O} 2 \\
\text { O3,O4,O5,O6) }\end{array}$ & $\begin{array}{l}\text { Mengembangkan fasilitas } \\
\text { fungsional pelabuhan } \\
\text { yang belum tersedia } \\
\text { (W6, O5,06,O7) }\end{array}$ \\
\hline
\end{tabular}

3. Kedekatan PPI Cisolok ke lokasi-lokasi pemasaran ikan (O3) 
4. Daerah Cisolok termasuk daerah wisata bahari potensial yang sedang berkembang $(\mathrm{O} 4)$

5. Dukungan DKP Kabupaten Sukabumi (O5)

6. Adanya dukungan/ keinginan nelayan, pedagang, pengolah ikan untuk pengembangan PPI Cisolok (O6)

7. Adanya peluang yang positif anggaran dana untuk pengembangan PPI Cisolok (O7)

\section{THREAT (T)}

STRATEGI (ST)

STRATEGI (WT)

1. Kondisi Cuaca/musim belum responsif terhadap armada PMT (T1)

Melakukan peningkatan
ukuran armada
penangkapan ikan
untuk mengatasi kondisi
cuaca/musim yang
belum responsif terhadap
armada PMT (S1,S2,T1)

2. Adanya nelayan

Cisolok yang mendaratkan dan memasarkan ikan langsung ke PPN Palabuhanratu (T2) armada PMT (S1,S2,T1)

Melakukan studi
master plan pelabuhan
untuk mengatasi
pendangkalan dan
memberikan kemudahan
serta keamanan bagi
armada penangkapan
keluar/masuk dari/ke
pelabuhan (W1,W2,T1)
Peningkatan jaringan
kerja sama dengan
pihak swasta untuk
menginvestasikan
dananya dalam
pengembangan PPI
Cisolok (W3,T3)

3. Belum ada anggaran

pengembangan

PPI Cisolok yang mencukupi (T3)

Berdasarkan faktor eksternal dan faktor internal yang telah digabungkan (Tabel 5), maka didapatkan strategi yang memungkinkan dan sesuai dengan kondisi pengembangan fasilitas-aktivitas kepelabuhanan perikanan di PPI Cisolok.

1. Strategi SO

SO1: Melakukan pembangunan fasilitas pokok (dermaga dan kolam pelabuhan) dan meningkatkan jumlah dan ukuran armada penangkapan ikan untuk memanfaatkan tingginya potensi sumberdaya ikan di WPP 573.

SO2: Menjalin kerjasama dengan para pengusaha untuk terlibat dalam kegiatan perencanaan dan pengembangan PPI Cisolok.

2. Strategi WO

WO1: Melakukan perbaikan breakwater dengan menambah panjang di sebelah kiri dan kanan pelabuhan, kemudian melakukan pengerukan sedimentasi, sehingga perahu dapat keluar/ masuk pelabuhan dengan aman.

WO2: Mengembangkan fasilitas fungsional pelabuhan yang belum tersedia.

3. Strategi ST

ST1: Melakukan peningkatan ukuran armada penangkapan ikan untuk 
mengatasi kondisi cuaca/musim yang belum responsif terhadap armada Perahu Motor Tempel (PMT).

4. Strategi WT

WT1: Melakukan studi master plan pelabuhan untuk mengatasi pendangkalan dan memberikan kemudahan serta keamanan bagi armada penangkapan keluar/masuk dari/ke pelabuhan.

WT2: Peningkatan jaringan kerja sama dengan pihak swasta untuk menginvestasikan dananya dalam pengembangan PPI Cisolok.

Strategi yang harus dilakukan pihak pengelola PPI Cisolok dalam upaya pengembangan fasilitas-aktivitas di PPI Cisolok, diringkaskan sebagai berikut: "Pembangunan secara bertahap dermaga dan kolam pelabuhan disertai perbaikan breakwater dan pengerukan sedimentasi, melakukan peningkatan ukuran dan jumlah armada penangkapan ikan untuk peningkatan aktivitas di PPI Cisolok".

\section{KESIMPULAN DAN SARAN}

\section{Kesimpulan}

Strategi yang dapat diterapkan dalam pengembangan fasilitas-aktivitas pendaratan ikan di PPI Cisolok meliputi: (1) Melakukan pembangunan secara bertahap fasilitas pokok (dermaga pendaratan ikan dan kolam pelabuhan), (2) Menjalin kerjasama dengan para pengusaha untuk terlibat dalam kegiatan perencanaan dan pengembangan PPI Cisolok, (3) Melakukan perbaikan breakwater, (4) Mengembangkan fasilitas fungsional pelabuhan yang belum tersedia, (5) Melakukan peningkatan ukuran armada penangkapan ikan, (6) Melakukan studi master plan pelabuhan, (7) Peningkatan jaringan kerjasama dengan pihak swasta untuk menginvestasikan dananya dalam pengembangan PPI Cisolok.

\section{Saran}

Berdasarkan penelitian yang sudah dilakukan saran yang diberikan adalah perlu pembangunan secara bertahap fasilitas pendaratan ikan secara optimal, agar nelayan dapat dengan aman dan nyaman melakukan pendaratan ikan di PPI Cisolok.

\section{UCAPAN TERIMA KASIH}

Penulis mengucapkan terima kasih yang sebesar-besarnya kepada pihak Pelabuhan PPI Cisolok, Dinas Kelautan dan Perikanan Kabupaten Sukabumi, dan semua pihak yang telah membantu dalam penelitian ini.

\section{DAFTAR PUSTAKA}

[BPS] Badan Pusat Statistika Kabupaten Sukabumi. 2018. Kecamatan Cisolok dalam Angka 2018. Sukabumi, Jawa Barat. BPS.

Dinas Perikanan Kabupaten Sukabumi. 2011. Masterplan Minapolitan. Sukabumi (ID): Departemen Kelautan dan Perikanan.

Hutapea RYF, Solihin I, Nurani TW. 2017. Peran Pelabuhan Perikanan Samudera Nizam Zachman dalam Mendukung Industri Tuna. Journal Marine Fisheries. 8: 187-198.

Indrayani L, Wibowo BA, Setiyanto I. 2017. Tingkat Kondisi dan Potensi Pelabuhan Perikanan di Kabupaten Sukabumi, Jawa Barat. Journal of Fisheries Resources Utilization Management and Technology. 6: 352-364.

[KKP] Kementerian Kelautan dan Perikanan Republik Indonesia. 2012. Peraturan Menteri KP Nomor 8 Tahun 2012 Tentang Kepelabuhan Perikanan. http: / / infohukum.kkp.go.id Maret 2020].

Lubis E, Mardiana N. 2011. Peranan Fasilitas PPI terhadap Kelancaran Aktivitas Pendaratan Ikan di Cituis Tangerang. Jurnal Teknologi Perikanan dan Kelautan. 1: 1-10.

Lubis E. 2012. Pelabuhan Perikanan. Bogor, Jawa Barat. IPB Press.

Pane AB. 2010. Kajian Kekuatan Hasil Tangkapan: Kasus Pelabuhan Perikanan Nusantara (PPN) Palabuhanratu Sukabumi. Jurnal Mangrove dan Pesisir. 10: 8-19.

Pane AB. 2017. Metode Skoring Dasar dan Pengembangannya. Bogor: Departemen Pemanfaatan Sumberdaya Perikanan, Fakultas Perikanan dan Ilmu Kelautan, Institut Pertanian Bogor.

Puspitasari N, Irnawati R, Susanto A. 2013. 
Strategi Pengembangan Pelabuhan Perikanan Nusantara Karangantu Kota Serang Provinsi Banten. Ilmu Pertanian dan Perikanan. 2: 159169.

Putri AS, Solihin I, Wiyono ES. 2017. Strategi Optimalisasi Fungsi Pelabuhan Perikanan dalam Pemasaran Hasil Tangkapan di PPP Lempasing. Journal Albacore. 1: 171-183.

Rosalia AA, Pane AB, Solihin I. 2018. Kebutuhan Fasilitas Pokok Pangkalan Pendaratan Ikan Cisolok 10 Tahun Mendatang. Journal Albacore. 2: 185-196.

Sinaga GV, Rosyid A, Wibowo BA. 2013. Optimalisasi Tingkat Pemanfaatan Fasilitas Dasar dan Fungsional di Pelabuhan Perikanan Samudera Nizam Zachman Jakarta dalam Menunjang Kegiatan Penangkapan Ikan. Journal of Fisheries Resources Utilization Management and Technology. 2: 43-55.

Suherman A. 2011. Formulasi Strategi Pengembangan Pelabuhan Perikanan Nusantara Pengambengan Jembrana. Journal Marine Fisheries. 2: 87-99.

Syahputra F. 2015. Analisis Pengembangan Fasilitas Pokok Pelabuhan Perikanan Pantai (PPP) Lampulo Banda Aceh [Tesis]. Bogor: Institut Pertanian Bogor.

Wahyudi DP. 2014. Analisis Persepsi Keberlanjutan Perikanan Tangkap Skala Kecil di Cisolok, Sukabumi, Jawa Barat [Tesis]. Bogor: Institut Pertanian Bogor. 